\title{
Arsenic, lead, and uranium concentrations on sediments deposited in reservoirs in the Rio Grande Basin, USA- Mexico border
}

\author{
Carmen G. Méndez-García \& Mayra Y. Luna-Porres \& María E. Montero-
} Cabrera \& Marusia Rentería-Villalobos \& Bernardo Pérez-Cázares \& Rafael García-Tenorio

\section{Abstract}

Purpose The El Granero reservoir is the last reservoir of the Rio Conchos before it joins the Rio Grande at the Mexico-USA border. This reservoir, together with the San Marcos reservoir, is located in the arid region of Chihuahua, Mexico. High, naturally occurring radioactivity levels, as well as high arsenic (As) concentrations, have been found in both reservoirs. The main goal of this research was to establish the spatial and temporal distribution of trace and radioactive elements in surface sediments and cores collected from these reservoirs. Materials and methods Sediment cores were dated using 210Pb and 137Cs measurements and applying the constant rate of sup-ply (CRS) model. Major, trace, and radioactive elements were determined in surface samples and three sediment cores.

Radioactive elements were determined by both alpha and gam-ma spectrometry. Major and trace elements were determined by inductively coupled plasma optical emission spectrometry (ICP-OES) using the EPA 3051a method. Enrichment factors $(E F)$, contamination factors (CF), and pollution load indexes (PLI) were calculated in order to identify the human impact in both reservoirs, whereas the chemical index weathering (CIW) was used to assess differences in the degree of weathering. 


\section{Results and discussion}

High uranium $(U)$ enrichment $(E F s=24.9-54.7)$ was observed in core layers at the San Marcos reservoir, while in surface sediments, this enrichment was lower. The high variability of lead $(\mathrm{Pb})$ and As in sediment cores from the Granero reservoir was attributed to human influence. Arsenic and $\mathrm{Pb}$ enrichment differences be-tween entry and exit sediment cores were explained by the filtering capabilities of the elongated shape, the topography, and the presence of plants on the reservoir's bed. The highest PLI was found at the entrance core of the Granero reservoir.

\section{Conclusions}

The natural element concentration levels of $\mathrm{As}, \mathrm{Pb}$, and $\mathrm{U}$ were established at the Granero reservoir. High EFs for As and $\mathrm{Pb}$ suggest an anthropogenic origin of these pollutants at specific time intervals. High $U$ concentrations in the San Marcos area are explained as naturally occurring. The concentrations of As in most of the studied sediments could pose a risk to human health by As ingestion, since they are above the probable effect level (PEL).

Keywords $210 \mathrm{~Pb}-137 \mathrm{Cs}$ dating. Arsenic. Fresh water sediments. Lead. Pollution indicators. Uranium

\section{Introduccion}

Arsenic (As) and lead $(\mathrm{Pb})$ are recognized as hazardous elemental pollutants (WHO 2012). Skin diseases, cancer, and impairment of neurobehavioral functions have been attributed to their ingestion or inhalation. On the other hand, 
overexposure to uranium $(\mathrm{U})$, detected by high concentration in urine, has been suggested to cause pathological alterations to the kidneys (Vicente-Vicente et al. 2010).

Numerous studies indicate that human activities, like industry, urbanization, agriculture, and domestic wastes, modify the trace element concentrations in the geochemical balance of aquatic environments (Ruiz-Fernández et al. 2005; Bertolino et al. 2007; Qi et al. 2010). Nevertheless, the source of trace pollutants may be the weathering products of the surrounding rocks. Sediments are important carriers of elements in the hydrological cycle; they also reflect the chemistry of a particular water system. Furthermore, a sediment core reflects the transformation they have undergone in the course of time and geochemical history (Ruiz-Fernández et al. 2007). Therefore, the study of sediments may provide clues to the trace elemental concentrations of natural and anthropogenic contaminants.

The state of Chihuahua is located in Mexico's northern border. A large part of the state has a semi-arid environment, while the Rio Conchos is the main pathway for surface water (INEGI 1999). The Rio Conchos basin is part of the Rio Grande basin, which is shared by Mexico and the United States of America. The low Rio Conchos region belongs to the physiographic province of Basin and Range. The basin of the Sacramento-Chuvíscar river system, which constitutes the last major tributary to the Rio Conchos, originates in the vicinity of a $U$ deposit in San Marcos, Chihuahua. There is also a water reservoir of the same name in the surrounding area. The "Luis L. Leon" or "El Granero" dam (INEGI 1999) artificially creates the last Rio Conchos reservoir before it joins the Rio Grande. The San Marcos and the 
Granero reservoirs are, therefore, sites of great interest for verifying the presence and origin of the three above-mentioned harmful chemical elements.

Some high $\mathrm{U}$ radioactivity concentrations in drinking water have been reported in Chihuahua City (Villalba et al. 2006). Several radioactive anomalies have also been found in the state of Chihuahua, and some of them are located in the San Marcos basin (Ferríz 1985). Both surface and ground waters are important resources in the area. The surface water gathered in the San Marcos reservoir is used for agricultural purposes, whereas groundwater from shallow and deep wells is used for both agricultural and domestic activities. Previous studies in the area have shown the presence of $U$ in surface waters, fish, and some plants (Rentería Villalobos et al. 2005; Montero Cabrera et al. 2007; Luna Porres et al. 2011; Burillo Montufar et al. 2012). Data of the reservoir's water contamination shows high Uspecific activities up to $7.7 \mathrm{~Bq} \mathrm{~L}^{-1}$. This high $\mathrm{U}$ concentration is attributed to the lixiviation and/or erosion of the uraniferous deposits located in this area. Thus, the San Marcos reservoir could be a sink for other elements that have not yet been analyzed (Rentería Villalobos et al. 2007; Reyes-Cortes et al. 2007, 2012).

On the other hand, $\mathrm{As}$ and $\mathrm{Pb}$ poisoning from ingestion and inhalation in Northern Mexico has been related to groundwater (Camacho et al. 2011), gasoline additives, and dust from smelters (Benin et al. 1999; Carrizales et al. 2006; Ornelas Hicks et al. 2006; Sanin et al. 2006). Elevated concentrations of As in both groundwater and sediments have been reported in Chihuahua State (Camacho et al. 2011; Gutierrez et al. 2012; Reyes-Gómez et al. 2013). Some authors have emphasized its possible geochemical origin (Reyes Cortés et al. 2006a; Reyes- 
Gómez et al. 2013). Some studies of sediments from the middle and lower basins of the Rio Conchos (Gutierrez et al. 2008) show that it is advisable to study the contents of As along the rivers. Gutierrez et al. (2008) also studied the distribution of As in the Rio Conchos basin, showing its enrichment in the area. Later, Gutierrez et al. (2009) reported the concentrations of As in sediments of the tributaries and the Rio Conchos itself, as well as in the reservoirs Las Virgenes and El Granero. The values obtained in the reservoirs are enriched with respect to the rivers. Therefore, it was concluded that the reservoirs may be becoming sinks of As, which threatens the water. Lead contamination of sediments in this region has been described by Gutiérrez and Carreon (2008) and Gutierrez et al. (2012). Thus, there is considerable interest in finding $\mathrm{As}$ and $\mathrm{Pb}$ fingerprints for other scenarios of the same region as the San Marcos reservoir. The analysis of their spatial and temporal behavior in environments located far from cities could shed some light on their geochemical origin and environmental persistence. The $U$ concentrations in sediments and water have not been reported before for the Granero reservoir.

The aim of this work is the investigation of trace element fingerprints of three sediment cores from two aquatic systems (the San Marcos and the Granero reservoirs) with different types of disturbances regarding the content of $\mathrm{As}, \mathrm{Pb}, \mathrm{U}$, and radioactive isotopes. It also establishes the potential risk to humans, by comparing the obtained concentrations with the threshold effects level (TEL) and probable effects level (PEL) (MacDonald 1994; Buchman 2008). A better understanding of the relationships of pollutants in the given reservoirs with either natural or anthropogenic origins, both spatially and temporally, is a further objective 
of the study. In order to assess enrichment factors (EF), the natural elemental concentration levels of $\mathrm{As}, \mathrm{Pb}$, and $\mathrm{U}$ in dated sediment layers were established by using aluminum normalization.

\section{Materials and methods}

\subsection{Study area}

\subsubsection{The San Marcos reservoir}

Figure $\underline{1}$ shows the geographic location of Chihuahua State, as well as of the two reservoirs studied. The San Marcos reservoir is located approximately $25 \mathrm{~km}$ west-northwest to Chihuahua City, Mexico.

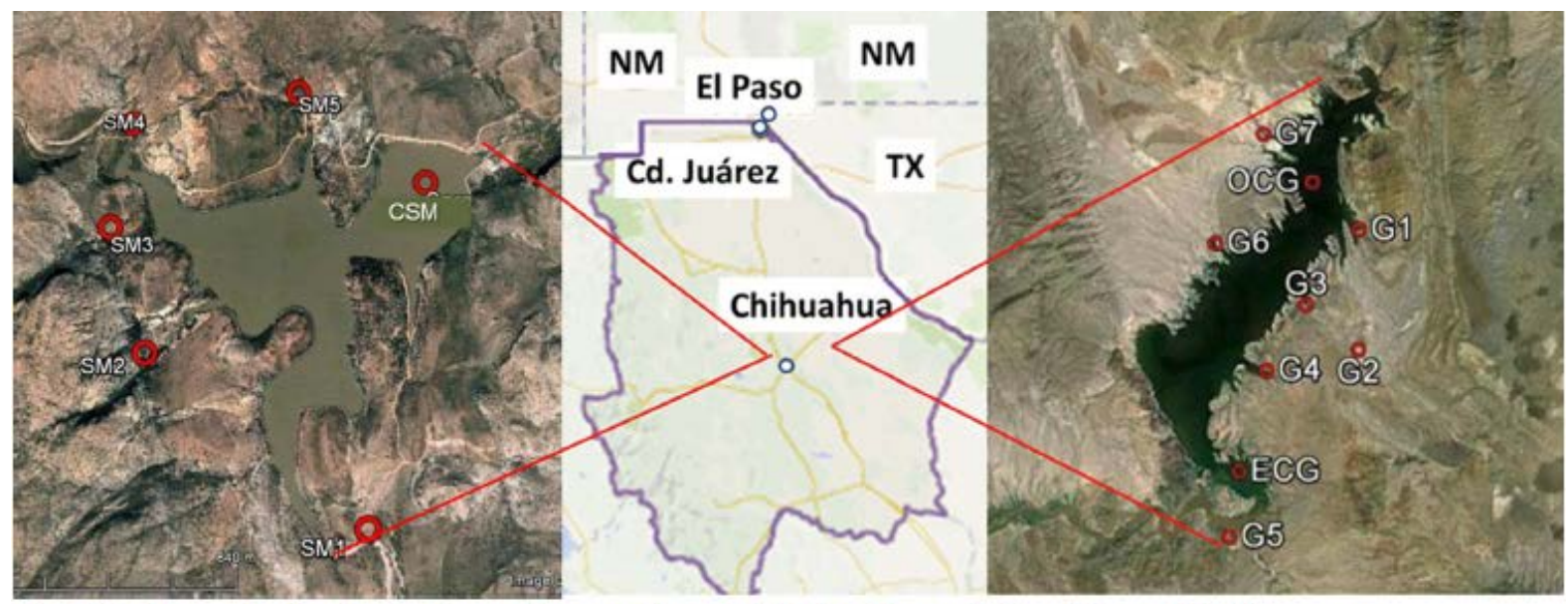

Fig. 1 Study area showing the location and the sampling points for San Marcos (left) and Granero (right) reservoirs

It was built at the beginning of the twentieth century. It has a capacity of 4.45 million $\mathrm{m}^{3}$ of water and is used for flooding control and agriculture. The San Marcos reservoir has a narrowing that divides it into two basins (west and east), and this may influence the sediment transport downstream along the lake (Fig. 1). Sediment core CSM was collected in the basin nearer to the dam's wall. This location is close to a spring located in the bed of the San Marcos reservoir. The San Marcos dam

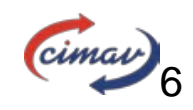


collects water that runs in the rainy seasons from the west, at the start of the creek of the same name and near to the Victorino $U$ deposit. Turbid water frequently occurs during these periods, also showing a high content of organic matter. The water level drops in the lake during periods of drought, and the water may look very clear.

\subsubsection{Geology of the San Marcos area}

The San Marcos reservoir is located at the Majalca National Park area, which is part of the transition from the east of the Sierra Madre Occidental to the Basin and Range province in the state of Chihuahua. The upper volcanic series of the Sierra Madre Occidental consists mainly of rhyolitic tuffs and some upper Cenozoic intermediate volcanic sequences. The lithology of the San Marcos reservoir area (Reyes-Cortés et al. 2010) (Fig. 2) mainly consists of volcanic and volcanoclastic rocks of rhyolitic composition in the form of dikes (TQm in Fig. 2) and resurgent rhyolite domes, as well as dikes (Do in Fig. 2) of intermediate to basic composition (Ferríz 1985). It also shows a few outcrops of Cretaceous limestone in the northern boundary of the basin (Reyes-Cortés et al. 2012). The Trampa-Picos Gemelos (TTpg) unit presents andesitic rocks. The $U$ deposits at San Marcos, named as Victorino and San Marcos 1 and their minerals, have been recently described by Reyes-Cortés et al. (2010). Mineral species found in the San Marcos deposits were as follows: uranophane and metatyuyamunite at the San Marcos 1 site; and uranophane, uraninite, masuyite, and becquerelite at the Victorino site 
(Reyes-Cortés et al. 2010).

\subsubsection{The Granero reservoir}

The Granero reservoir is located approximately $90 \mathrm{~km}$ northeast of Chihuahua City. It was built in 1968 with a water capacity of 854 million $\mathrm{m}^{3}$. The reservoir's water is used for a fish hatchery, and for agricultural and domestic use. The elongated basin of the reservoir has a length of $\sim 12 \mathrm{~km}$ (see Fig. 1). Its relatively recent construction on a rough relief area, with a steady stream of water, produced a reservoir bed that is abundant in vegetation (including submerged trees). Vegetation and topography might play the role of filtering the dissolved and suspended material while the water flows along the reservoir. The lithology of the area is described below.

\subsubsection{Geology of the Granero area}

The geological basement of the Granero reservoir is correlated to Precambrian metamorphic rocks such as metagranite, amphibolite, and gneiss; the reverse-thrusting faults in the area represent a Paleozoic tectonic compression (Greenville Orogeny) (Hernández Noriega et al. 2002). The sequence continues with the Paleozoic exposure. These units are shown as epiclastic rocks, lutites, sandstones, and limolites culminating with paleofluvial deposits of Fm. Verde. Most of the geological settings in the surroundings of the Granero reservoir are Jurassic limestone-sandstones (Fm. La Casita) and Creteaceous limestones and evaporites (Fm. Navarrete, Vigas, Cuchillo, 
https://cimav.repositorioinstitucional.mx/

Benigno, Tamaulipas, Bronce, Aurora, and Loma de Plata) (SGM 2002). Most of the structural setting is proved

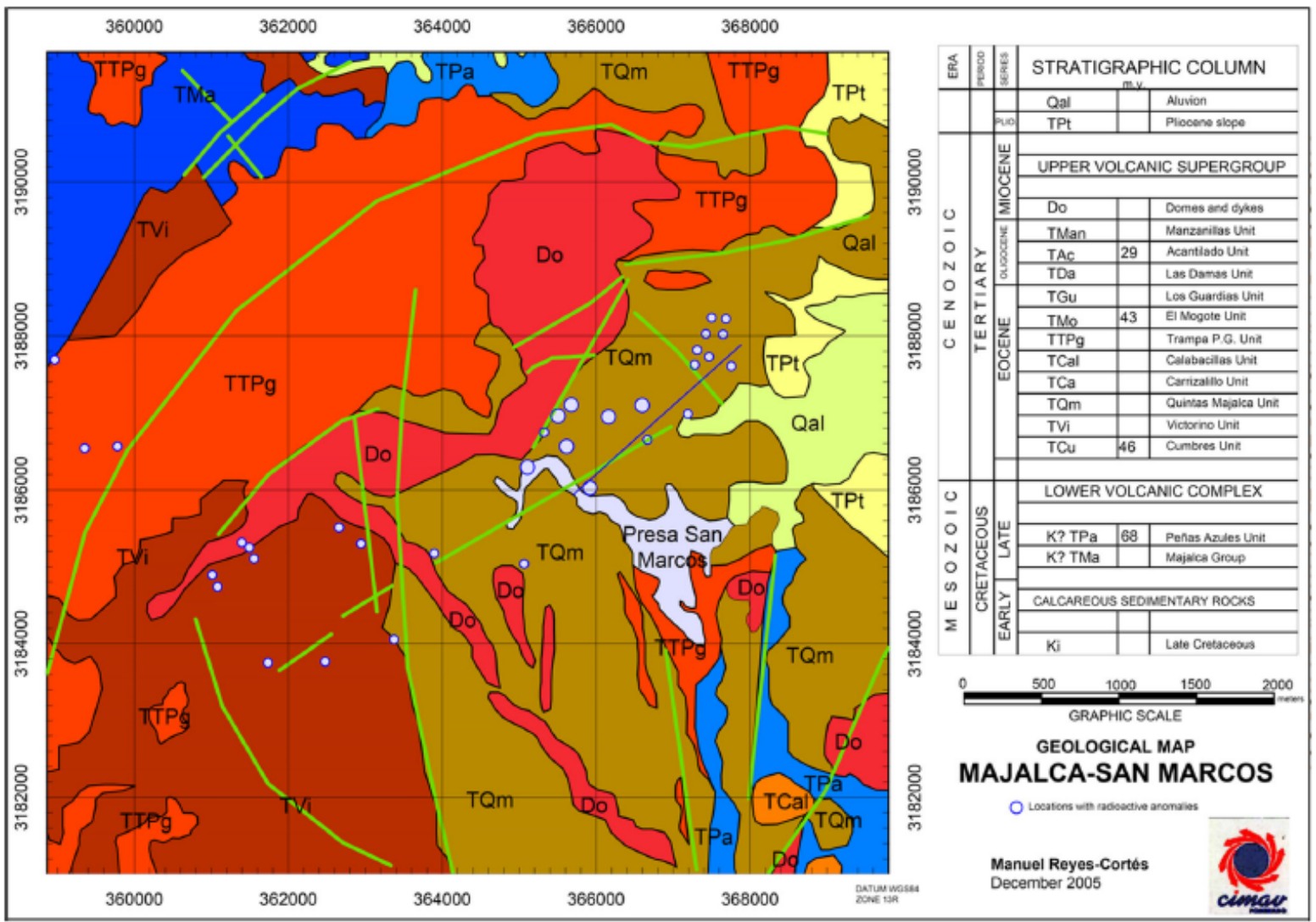

Fig. 2 Geological map of San Marcos reservoir zone

with the Basin and Range distention province, shown as normal faults striking NW, related with the extrusion of volcanic and plutonic igneous rocks (ToTR, ToGd, and ToGr in Fig. $\underline{3}$ ) all of them from the Cenozoic era. Finally, the most recent rocks in the Granero area are Miocenic and Holocenic conglomerates (TmCgp in Fig. 3 ) and alluvial deposits (Qholm and QpthoCgp in Fig. $\underline{3}$ ), overlaying conformably the older rocks (Hernández Noriega et al. 2002). 


\subsection{Sampling}

Three sediment cores were collected manually by a steel tube $(7-\mathrm{cm}$ diameter and $40-\mathrm{cm}$ length). One sediment core was collected at a depth of $20 \mathrm{~m}$ from the San Marcos reservoir in September 2007 (CSM), at the outlet zone, at $100 \mathrm{~m}$ from the dam's wall (see Fig. 1). The two cores from the Granero reservoir were collected at a depth of $10 \mathrm{~m}$, one at the reservoir's entrance (ECG) and the other at the outlet zone (OCG) in April 2012 (see Fig. 1). Surface sediment samples were also collected from several places around the reservoirs. Table $\underline{1}$ shows the details of the location of the sediment cores and surface sediment samples.

\subsection{Laboratory analysis}

The three cores were cut into 2-cm-thick sections. Each of them was dried at $55^{\circ} \mathrm{C}$ to constant weight. Afterwards, they were ground into a powder with an agate mortar pestle. Finally, they were homogenized by sieving to $<63-\mu \mathrm{m}$ grain size and packed for further analysis.

To obtain ${ }^{238} \mathrm{U}$ and ${ }^{234} \mathrm{U}$ activity concentrations (AC), all samples were spiked with ${ }^{232} \mathrm{U}$ and submitted to radioanalytical procedure. Total sample dissolution was reached at open air acid digestion by using $\mathrm{HFc}$ and $\mathrm{HNO}_{3} \mathrm{C}(10: 10)$. Uranium extraction was carried out by chromatography, using UTEVA resins. Then, U was 
electrodeposited on a stainless steel disc. Radiochemical yield was determined by the ${ }^{232} \mathrm{U}$ counting rate (Talvitie $\underline{1972}$; Hallstadius $\underline{1984}$; Méndez et al. $\underline{2010}$ ).

The ${ }^{238} \mathrm{U},{ }^{234} \mathrm{U}$, and ${ }^{210} \mathrm{Po}$ ACs were obtained by alpha activity measurements, using an Alpha Analyst spectrometer (CANBERRA, Meriden, USA).

The activity of ${ }^{210} \mathrm{Po}$ was determined by alpha counting. The powder was digested with aqua regia (1:2), and ${ }^{210} \mathrm{Po}$ was extracted using the technique of liquidliquid extraction with tributyl phosphate (TBP), auto deposited on cupper discs, and also measured using an Alpha Analyst spectrometer. Samples

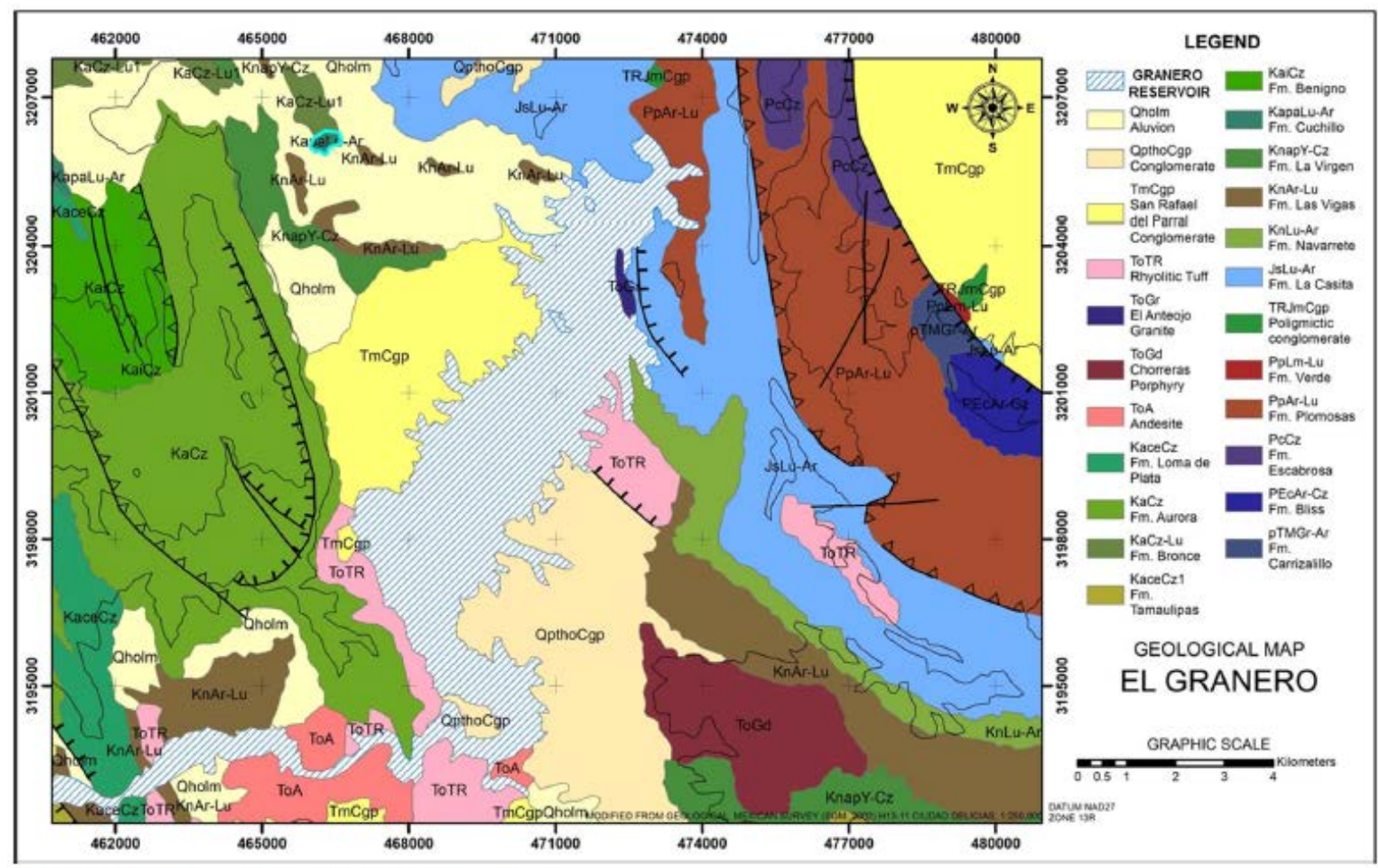

Fig. 3 Geological map of Granero reservoir zone

were spiked with ${ }^{209} \mathrm{Po}$ as radiotracer yield (García-Tenorio García-

Balmaseda 1986; Sanchez-Cabeza et al. 1998; Aslani et al. 2005).

All sections from the sediment cores and the surface samples were analyzed 
for ${ }^{238} \mathrm{U}$ - and ${ }^{232} \mathrm{Th}$-series isotopes

Table 1 Sampling details of cores and surface sediments as collected at San Marcos and Granero reservoirs' areas

\begin{tabular}{llll}
\hline Reservoir & Sediment type & Sample ID & Location (latitude, longitude) \\
\hline San Marcos & Core & CSM & $28.74174,-106.35683$ \\
& Surface & SM1 & $28.77962,-106.35839$ \\
& Surface & SM2 & $28.78555,-106.36757$ \\
& Surface & SM3 & $28.78999,-106.36956$ \\
& Surface & SM4 & $28.79408,-106.36915$ \\
& Surface & SM5 & $28.79525,-106.36228$ \\
Granero & Core & ECG & $28.88401,-105.30953$ \\
& Core & OCG & $28.95626,-105.29211$ \\
& Surface & G1 & $28.94499,-105.27856$ \\
& Surface & G2 & $28.91572,-105.27756$ \\
& Surface & G3 & $28.92618,-105.29260$ \\
& Surface & G4 & $28.90981,-105.30293$ \\
& Surface & G5 & $28.86896,-105.31165$ \\
& Surface & G6 & $28.94045,-105.31855$ \\
& Surface & G7 & $28.96748,-105.30624$ \\
\hline
\end{tabular}

(reported here as ${ }^{226} \mathrm{Ra}$ and ${ }^{228} \mathrm{Ra}$ ), as well as for ${ }^{40} \mathrm{~K}$ and ${ }^{137} \mathrm{Cs}$ activities, by high-resolution gamma spectrometry using an HPGe detector (CANBERRA, Meriden, USA). Prior to the analysis, aliquots around $20 \mathrm{~g}$ were stored in Petri dishes (15-mm height per 75 diameter capacity) and hermetically sealed for at least 21 days in order to reach radioactive equilibrium between ${ }^{226} \mathrm{Ra}$ and progenies. The detector was calibrated using certified reference materials RGU, RGTh, and RGK IAEA in the same geometry as the measured samples. The counting time was $48 \mathrm{~h}$. The analytical precision (repeatability) of measurements was around $10 \%$, obtained by the repeat measurement of five randomly selected samples. Accuracy above $85 \%$ was estimated by the analysis of the certified material IAEA-375, with recommended values for ${ }^{232} \mathrm{Th}$-series isotopes, ${ }^{226} \mathrm{Ra}$ daughters, ${ }^{137} \mathrm{Cs}$, and ${ }^{40} \mathrm{~K}$. Considering the appropriate corrections for laboratory background, the activity 
of ${ }^{226} \mathrm{Ra}$ was obtained from the $609 \mathrm{keV}$ line of ${ }^{214} \mathrm{Bi},{ }^{40} \mathrm{~K}$ activity from its $1461 \mathrm{keV}$ line; ${ }^{228} \mathrm{Ra}$ activity was estimated from the $911 \mathrm{keV}$ line of ${ }^{228} \mathrm{Ac}$ and ${ }^{137} \mathrm{Cs}$ from its $662 \mathrm{keV}$ line.

For dating, total ${ }^{210} \mathrm{~Pb}$ tot activities were estimated by either the technique described above for measuring the activity of ${ }^{210} \mathrm{Po}$, or using its $46.54 \mathrm{keV} \mathrm{y}$-ray by high-resolution spectrometry, where secular equilibrium from ${ }^{226} \mathrm{Ra}$ to ${ }^{210} \mathrm{~Pb},{ }^{210} \mathrm{Bi}$, and ${ }^{210} \mathrm{Po}$ in the sediment after packing was assumed (Abril 2003). The sediment accumulation rate was obtained by the activity in excess of ${ }^{210} \mathrm{~Pb}_{\text {exc }}$, as calculated from the difference of total and supported ${ }^{210} \mathrm{~Pb}$. Supported ${ }^{210} \mathrm{~Pb}_{\text {sup }}$ activity was considered equal to ${ }^{226} \mathrm{Ra}$ activity, by the secular equilibrium with its progenies attained before the measurement.

Major and trace element analyzes were performed by inductively coupled plasma optical emission spectrometry (ICP-OES), using a Thermo Jarrell Ash IRIS/AP spectrometer (Waltham, Mass., USA), after microwave digestion applying the EPA 3051a method. Replicate measurements $(n=5)$ of the certified material IAEA-SL1 (trace and minor elements in lake sediments) showed an accuracy $>90 \%$ and a precision $>10 \%$ for most of the analyzed elements. Concentrations were obtained after three measurements per elements, and they are expressed in $\mathrm{mg}$ $\mathrm{kg}^{-1}$.

\subsection{Dating}

The activity of ${ }^{210} \mathrm{~Pb}_{\text {exc }}$ (unsupported) was calculated in all the sediment cores in order to know which dating model would be applied (García-Tenorio GarcíaBalmaseda 1986). 


$$
{ }^{210} \mathrm{~Pb}_{\text {exc }}={ }^{210} \mathrm{~Pb}_{\text {total }}-{ }^{210} \mathrm{~Pb}_{\text {sup }}
$$

The constant rate of supply (CRS) model was selected. This model assumes that the supply of ${ }^{210} \mathrm{~Pb}_{\text {exc }}$ to the sediment is constant through time (Sanchez-Cabeza et al. 2012), although the profile of this isotope may reflect the interaction of the sedimentation rate (SR) and radioactive decay, implying that ${ }^{210} \mathrm{~Pb}_{\text {exc }}$ and $\mathrm{SR}$ can be variable through time.

In this model, the age $t$ of each section at depth $z$ can be estimated as:

$$
t=\frac{1}{\lambda_{\mathrm{Pb}}} \ln \left(\frac{I(0)}{I(z)}\right)
$$

Where $I(0)\left(\mathrm{Bq} \mathrm{m}^{-2}\right)$ is the total ${ }^{210} \mathrm{~Pb}_{\text {exc }}$ inventory of the sediment core and $I(\mathrm{z})$ is the total ${ }^{210} \mathrm{~Pb}_{\text {exc }}$ in the sediment layer below depth $z$.

The sedimentation rate $R\left(\mathrm{~kg} \mathrm{~m}^{-2}\right.$ year-1) is obtained directly from:

$$
R=\frac{\lambda_{\mathrm{Pb}} I(z)}{A(z)}
$$

The sedimentation rate $S_{i}$ for each section $(\mathrm{cm}$ year-1) is calculated using the density value:

$$
S_{i}=\frac{R_{i}}{\rho_{i}} \times 100
$$

Estimated ages obtained by applying this method were confirmed by comparison with the fallout ${ }^{137} \mathrm{Cs}$ activity measurements. The ${ }^{137} \mathrm{Cs} \mathrm{AC}$ in sediment 
profiles has a peak in the vicinity of 1962-1964 from nuclear bomb testing in the atmosphere of the northern hemisphere (Ritchie and McHenry 1990; Walling and He 1997). It has another peak from the radionuclide dispersion produced by the Chernobyl accident in 1986 (Appleby et al. 1988; Garcia Agudo 1998; AlonsoHernandez et al. 2006).

\subsection{Sediment pollution quantification}

For classification and identification of the origin of trace element contents in sediment samples, the enrichment factor (EF), the contamination factor (CF), and the pollution load index (PLI) were calculated (Hakanson 1980; Tomlinson et al. 1980; Varol 2011; Pandey et al. 2016). The EF allows for differentiating the elements that originated from human activities from those of natural weathering. In such situations, it is useful to use normalization ratios (Shumilin et al. 2002; Zhang and Liu 2002). The concentration values for trace elements were normalized using aluminum (Al), determined for the same sample, as a proxy for the assessment of anomalous metal contribution. The EF was calculated using (Zoller et al. 1974; Reimann and Caritat 2000):

$$
\mathrm{EF}=\frac{\left(\mathrm{TE}_{\text {sample }} / \mathrm{Al}_{\text {sample }}\right)}{\mathrm{TE}_{\text {background }} / \mathrm{Al}_{\text {background }}}
$$

where $T E_{\text {sample, background }}$ are the trace element concentrations in each section of sediment core or a reference value for background, respectively, and $\mathrm{Al}_{\text {sample, background }}$ is the Al concentration in the sample or the background for each core (Schropp et al. 1990). Here, the Al, As, and $\mathrm{Pb}$ background concentration values employed for this normalization were extracted from published data of volcanic and sedimentary 
rocks at the Chihuahua environment (Cameron et al. 1980; Gutierrez et al. $\underline{2008}, \underline{2012})$.

The scale used to interpret the results of the EF was adapted from Birch and Olmos (2008), which provides the following values: EF < 3: zero or null enrichment; 3-10: moderate enrichment; 10-25: severe enrichment; $25-50$ : very severe enrichment; and >50: extremely severe enrichment.

The contamination factor (CF) shows the anthropogenic influence in the study area. The CF is calculated for each sample (Hakanson 1980) using:

$$
\mathrm{CF}_{i}=\frac{C_{i}}{B_{j}}
$$

Where $C_{i}$ is the concentration of the analyzed element in the sample $i$, and $B_{j}$ is the background concentration for the element $j$. The natural concentration level for contaminants in sediments was applied as background.

A CF $<1$ means that the sample is not polluted; CF: 1 means from not polluted to moderately polluted; 2 : moderately polluted; 3 : moderately to strongly polluted; 4: strongly polluted; 5 : strongly to very strongly polluted; and 6: very strongly polluted.

The PLI allows for determining the contamination factor of all the elements for samples with high CF. It is calculated using (Tomlinson et al. 1980):

$$
\mathrm{PLI}=\left(\mathrm{CF}_{1} \times \mathrm{CF}_{2} \times \mathrm{CF}_{3} \times \ldots \mathrm{CF}_{n}\right)^{1 / n}
$$

PLI values $<1$ suggest no pollution load and a value $>1$ indicates the presence of pollution in the sample set.

The chemical index weathering (CIW) is an improved measure of the degree 
of weathering experienced by a material relative to its source rock (Harnois $\underline{1988)}$ ). It is calculated using:

$$
\mathrm{CIW}=\mathrm{Al}_{2} \mathrm{O}_{3} /\left(\mathrm{Al}_{2} \mathrm{O}_{3}+\mathrm{CaO}+\mathrm{Na}_{2} \mathrm{O}\right)
$$

where $\mathrm{Al}_{2} \mathrm{O}_{3}, \mathrm{CaO}$, and $\mathrm{Na}_{2} \mathrm{O}$ are in molecular proportions. In this index, $\mathrm{Al}_{2} \mathrm{O}_{3}$ is used as the immobile component, while $\mathrm{CaO}$ and $\mathrm{Na}_{2} \mathrm{O}$ are the mobile components because they are readily leached during weathering. In this study, CIW values are employed for giving general considerations about sediment weathering and leaching in each study area.

\subsection{Statistical analysis}

Concentration results of trace element $(\mathrm{As}, \mathrm{Pb}$, and $\mathrm{U})$ for core and surface sediment were statistically analyzed using the Minitab 16 Statistical Software. The coefficient of variation (CV) was calculated as the standard deviation divided by the mean value of the elemental or the activity concentrations. It was obtained for each group of samples from the two reservoirs. To reveal whether there are significant differences $(p<0.05)$ between sediment types, an ANOVA one-way approach was performed. When, for a given variable, factors producing significant effects were found, an ANOVA followed by the Tukey posthoc test was run to assign differences to treatment level. The Pearson correlation coefficient was calculated to examine the relationships between (1) concentrations of trace elements in sediments of different locations in the same reservoir, and (2) rainfall periods and sedimentation rates for the sediments cores. 


\section{Results}

Figures $\underline{4}$ to $\underline{6}$ show the depth profiles for the concentration data related with dating, trace elements and radioisotope activities, respectively. Table $\underline{2}$ shows the concentration ranges of the assayed elements in the core and surface sediments.

SEDIMEN T C ORES

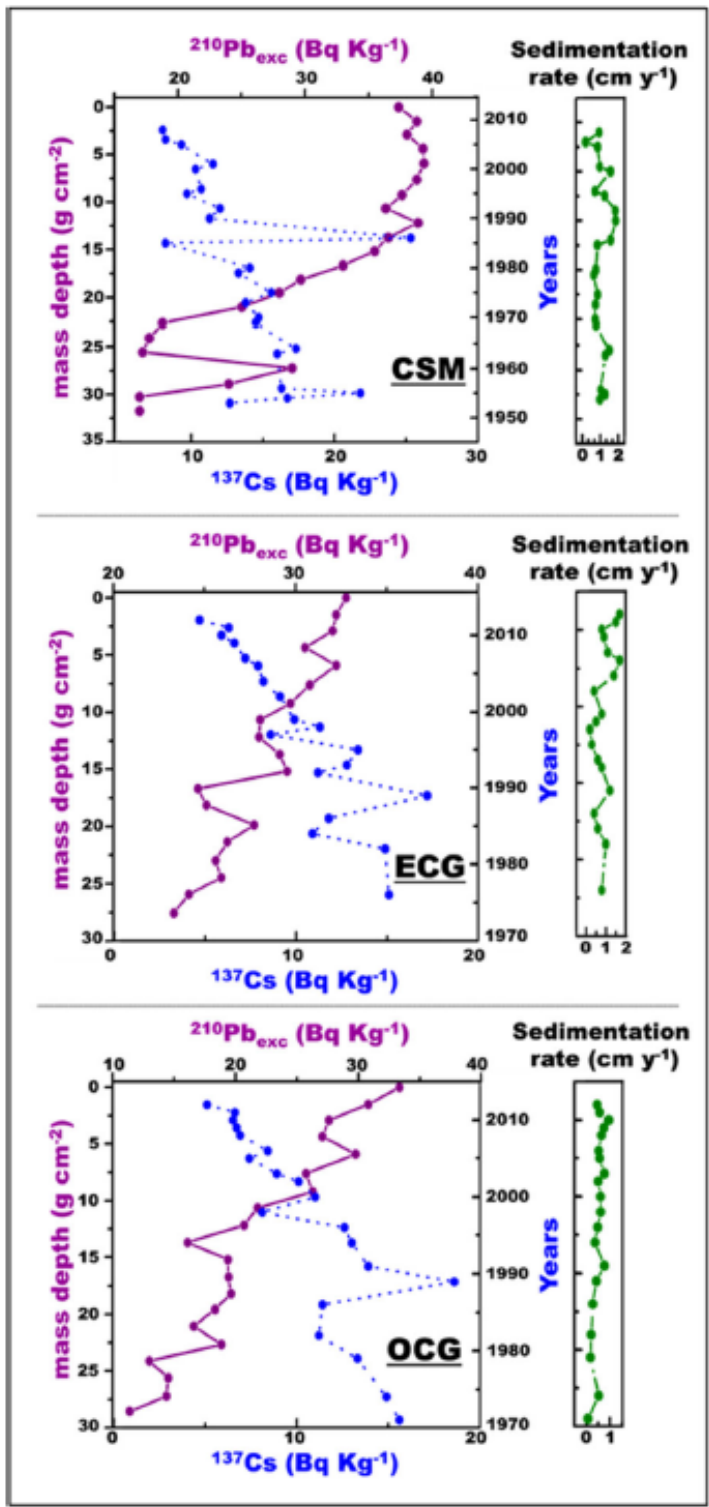

- $-{ }^{210} \mathrm{~Pb}_{\text {exe }} \quad \cdots-{ }^{137} \mathrm{Cs} \quad-\mathrm{O}-$ Sedimentation rate

Fig. $4{ }^{210} \mathrm{~Pb}_{\text {exc }}$ concentration values, ${ }^{137} \mathrm{Cs}$ concentration activities, and sedimentation rate profiles in sediment cores. CSM means core from San Marcos reservoir, ECG-entrance core from Granero reservoir, and OCG-northern core from Granero reservoir 


\subsection{Dating}

The total ${ }^{210} \mathrm{~Pb}_{\text {tot }}$ activities ranged from 84 to $313 \mathrm{~Bq} \mathrm{~kg}^{-1}$, and the supported ${ }^{210} \mathrm{~Pb}_{\text {sup }}$ activity from the San Marcos core sediments varied from 60 to $275 \mathrm{~Bq} \mathrm{~kg}{ }^{-1}$. The ${ }^{210} \mathrm{~Pb}_{\text {exc }}$ inventory in CSM was estimated to be $207.5 \pm 4 \mathrm{~Bq} \mathrm{~m}^{-2}$, the mean ${ }^{210} \mathrm{~Pb}_{\text {exc }} \mathrm{AC}$ was $34.8 \mathrm{~Bq} \mathrm{~kg}{ }^{-1}$ and its distribution did not show a monotonic behavior whereby the CRS dating model was applied. 


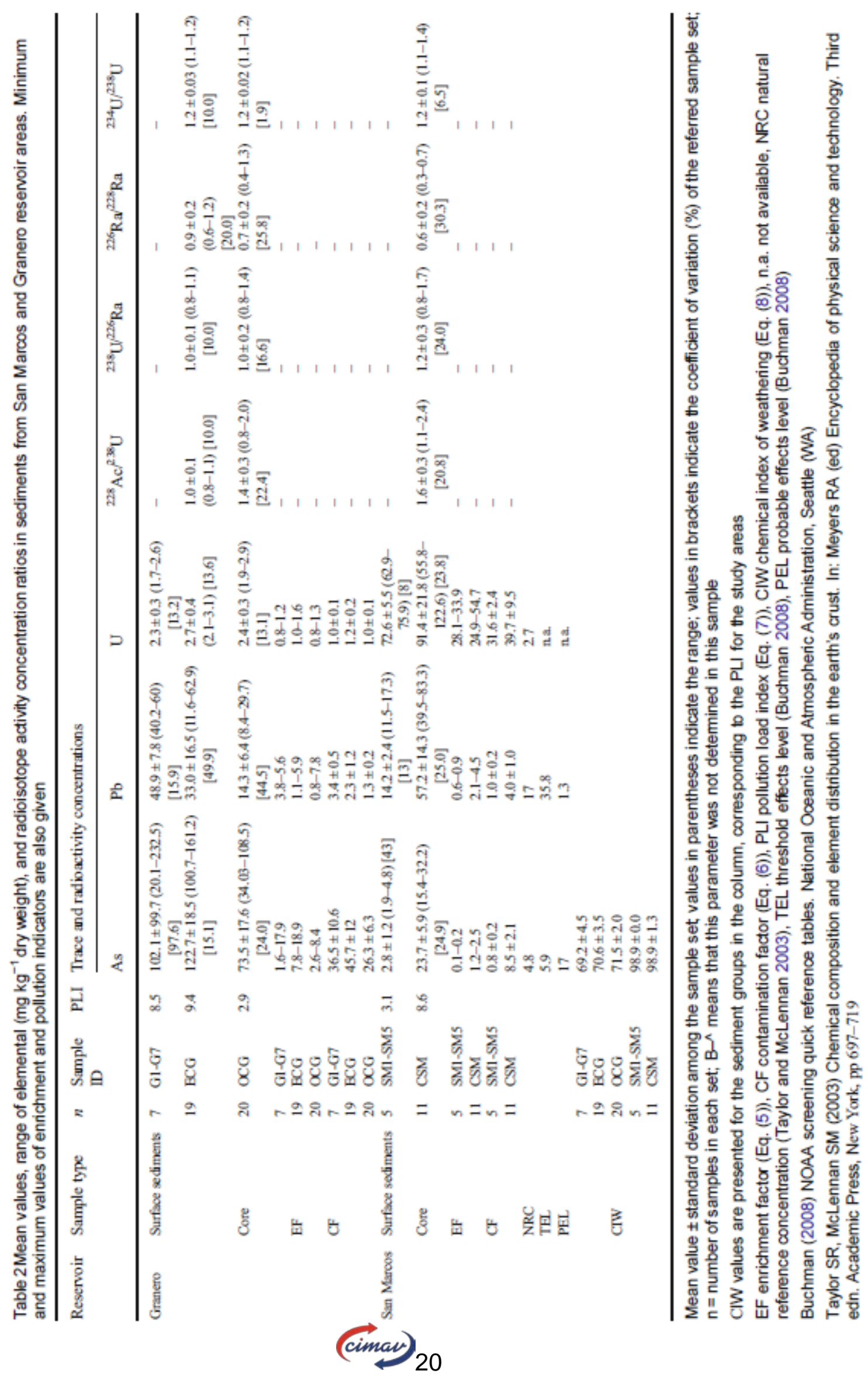


The ${ }^{210} \mathrm{~Pb}_{\text {exc }}$ distribution is characterized by a near exponential decline, a typical behavior of undisturbed soils. The CRS model employed was corroborated by ${ }^{137} \mathrm{Cs}$ activities, where its maximum concentration was found at $36-\mathrm{cm}$ depth, belonging to the 1963 weapons fallout peak, and at $16-\mathrm{cm}$ depth, related to the Chernobyl accident in 1986 (Fig. 4). Results obtained by the CRS method were accepted, as there is no discrepancy with the ${ }^{137} \mathrm{Cs}$ marker. The sedimentation rate calculated by Eq. (יㅡ) shows high variability with time. These results were compared with rainfall data in the region (see Electronic Supplementary Material, Appendix 1 Fig. A1.1), and a high correlation $(r=0.89)$ was observed. Consequently, the low values in the sedimentation rate belong to drought seasons, and, conversely, the high sedimentation rates are associated with periods of high rainfall contribution to the reservoir.

Both the entrance and northern sediment cores (ECG and OCG) extracted from the Granero reservoir also show a non-monotonic distribution of ${ }^{210} \mathrm{~Pb}_{\text {exc }}$ concentration with depth, but decrease exponentially with depth. Consequently, CRS dating model was also applied to these. The ${ }^{210} \mathrm{~Pb}_{\text {tot }}$ activities ranged from 48 to $59 \mathrm{~Bq} \mathrm{~kg}^{-1}$, and 41 to $55 \mathrm{~Bq} \mathrm{~kg}^{-1}$ for ECG and OCG, respectively. The ${ }^{210} \mathrm{~Pb}_{\text {exc }}$ inventory in ECG and OCG was estimated to be $194 \pm 5$ and $179 \pm 3 \mathrm{~Bq} \mathrm{~m}^{-2}$, respectively. The age calculated for the deepest layer of the ECG was 1976 , whereas for the OCG, it was 1971 . The maximum ${ }^{137} \mathrm{Cs}$ activity concentration was found around 1989 in both cases, which suggests the acceptance of the dating model applied in this reservoir by the fingerprint of the Chernobyl 
accident fallout (Fig. 4). The sedimentation rates in the ECG are correlated with rainfall $(r=0.708)$ but not in the case of OCG. This could be due to the variability of the annual water discharge from the dam, producing changes in the sedimentation rates at this point, which is closer to the dam wall.

\subsection{Trace elements}

Elemental concentrations of $\mathrm{As}, \mathrm{Cd}, \mathrm{Co}, \mathrm{Cr}, \mathrm{Ni}, \mathrm{Pb}, \mathrm{Sr}, \mathrm{Zn}$, and $\mathrm{U}$ were obtained by ICP-OES, and their EFs were calculated using Eq. (므). However, only As, $\mathrm{Pb}$, and $\mathrm{U}$ show high EF (Table 2 ). The CIW results show a high weathering in the San Marcos area, especially at the surface sediments; all sampling points show values $>98 \%$. Considering the composition of the typical rhyolitic parent rocks (Cameron et al. 1980; Reyes-Cortés et al. 2010), the leaching of sodium by weathering may be concluded. The little difference between CIW index values for surface sediments and sediment cores reflects the same amount of chemical weathering experienced by the weathered material. Nonetheless, there are appreciable $\mathrm{As}, \mathrm{Pb}$, and $\mathrm{U}$ concentrations in sediments of the San Marcos area.

In San Marcos sampling sites, concentration values for $\mathrm{As}$ and $\mathrm{Pb}$ in surface sediments appear lower than those of core sediments. Therefore, their EFs are lower than those in dated sediments. This feature suggests that both $\mathrm{As}$ and $\mathrm{Pb}$ come from sites located farther from the reservoir and that those elements are accumulating in the reservoir's bed (Table $\underline{2}$ and Fig. $\underline{5}$ ).

In core samples of the San Marcos reservoir, EF values for $\mathrm{Pb}(2.1-4.5)$ 
reflect a moderate to severe enrichment; for As (1.2-2.5), EF values imply a moderate enrichment, and for $U$ (24.9-54.7), EF values reflect a very severe enrichment (Table 2). The EF values suggest the following: (a) trace element concentrations of these elements are due to the nature of the characteristic rocks where the reservoir is located, and (b) the elemental concentrations are attributed to erosion of the uraniferous deposits located in the San Marcos area. The mean $U$ concentration in the sediment core at San Marcos is greater than in the surface sediments. The high concentrations of $U$ found in most of the surface sediments (Table A3, see Electronic Supplementary Material, Appendix 3) could be 


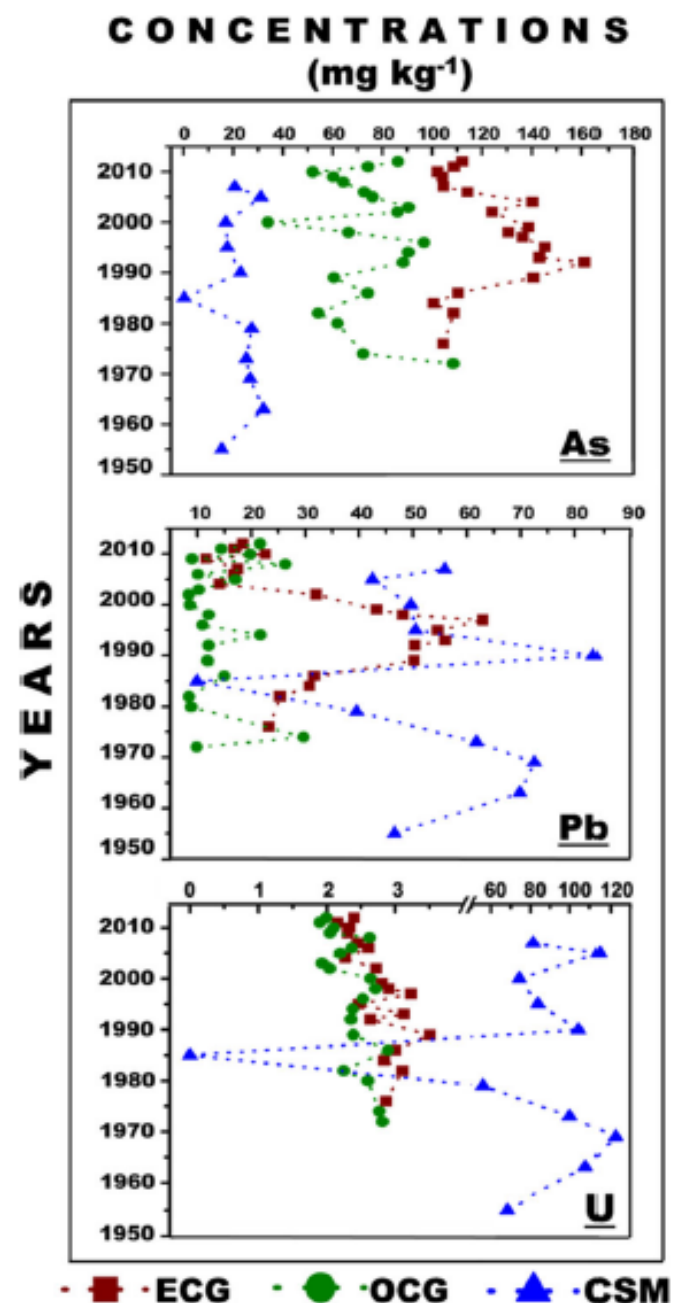

Fig. 5 Trace element concentration profiles in $\mathrm{mg} \mathrm{kg}^{-1}$ for all three dated sediment cores. Dotted lines represent the reference values for the upper Earth crust (Taylor and McLennan 2003). CSM means core from San Marcos reservoir, ECG-entrance core from Granero reservoir, and OCG-outlet core from Granero reservoir

explained by the location of sampling because they are close to the $U$ deposits of Victorino and San Marcos I. Previous studies on $U$ around the reservoir have found concentration values in sediments with mean values equal to $36.3 \mathrm{mg} \mathrm{kg}^{-1}$ (see Table A4, Electronic Supplementary Material, Appendix 4) (Rentería Villalobos et al. 2007), whereas rocks and sediments closer to Victorino deposit were 60 and $70 \mathrm{mg} \mathrm{kg}^{-1}$. In sediments directly on $U$ deposits, a value of 
$337 \mathrm{mg} \mathrm{kg}^{-1}$ has been reported (Luna Porres et al. 2011). Previous assays (ReyesCortés et al. $\underline{2010})$ found some $U$ minerals such as uraninite $\left(\mathrm{UO}_{2+x}\right)$, metatyuyamunite $\left(\mathrm{Ca}\left(\mathrm{UO}_{2}\right)_{2}\left(\mathrm{~V}_{2} \mathrm{O}_{8}\right) \cdot 3\left(\mathrm{H}_{2} \mathrm{O}\right)\right)$, uranophane $\left(\mathrm{Ca}\left(\mathrm{UO}_{2}\right)_{2} \mathrm{Si}_{2} \mathrm{O}_{7} \cdot 6\left(\mathrm{H}_{2} \mathrm{O}\right)\right)$, and becquerelite $\left(\mathrm{Ca}\left(\mathrm{UO}_{2}\right)_{6} \mathrm{O}_{4}(\mathrm{OH})_{6} \cdot 8\left(\mathrm{H}_{2} \mathrm{O}\right)\right)$.

Moreover, in the sediment core CSM, the CF average was $39.7,8.5$, and 4.0 for $\mathrm{U}, \mathrm{As}$, and $\mathrm{Pb}$. These values suggest that the influence of natural $\mathrm{U}$ deposits in the area is retained in the core, while the increase of $\mathrm{As}$ and $\mathrm{Pb}$ could also be attributed to rocks surrounding the reservoir. In surface sediments at the San Marcos site, the average pollution factor CF for trace elements, that showed high EF values, was 31.6, 0.8 , and 1.0 for $\mathrm{U}, \mathrm{As}$, and $\mathrm{Pb}$, respectively. These values confirm that the area has been naturally affected only in the case of U. The PLI value in SM surface sediments (Eq. (ㅁ)) is then equal to 3.1 and may be completely attributed to $\mathrm{U}$ while, for the sediment core CSM, this indicator is naturally affected by $\mathrm{As}, \mathrm{Pb}$, and $U$ and increases up to 8.6 .

Lead was also reported with a mean value of $14.5 \mathrm{mg} \mathrm{kg}^{-1}$ in suspended sediments from the reservoir (see Table A4) (Rentería-Villalobos et al. 2012). For instance, $\mathrm{Pb}$ was found in the rocks of Victorino $\mathrm{U}$ deposit as masuyite $\mathrm{Pb}\left(\mathrm{UO}_{2}\right)_{3} \mathrm{O}_{3}(\mathrm{OH})_{2} \cdot 3\left(\mathrm{H}_{2} \mathrm{O}\right)$ (Reyes-Cortés et al. 2010).

Arsenic concentration in the water column of the San Marcos reservoir could be one factor contributing to the As presence in sediments. The natural occurrence of As in the environment at the Chihuahuan Desert and the western USA has been attributed to a set of geological conditions instead of a specific type of geologic formation (Welch et al. 1988; Camacho et al. 2011). These conditions comprise one 
or more sediments, As-bearing mineral deposits, and volcanic rocks. This is the case, for instance, of the lead and zinc deposits of hydrothermal origin in carbonate rocks, with the presence of pyrite, chalcopyrite, and arsenopyrite, like in Naica, Santa Eulalia, Bismark, and La Encantada, in Chihuahua, and Shafter, Texas (Wendt 2002). Furthermore, As has been associated with $U$ deposits in the western USA (Welch et al. 1988). In addition, evidence shows that the rocks containing As are an important source of this element in the Chihuahuan Desert (Flores-Tavizón et al. 2003; Fierro et al. 2009; Camacho et al. 2011), and they contribute to its content in groundwater.

Significant correlations found between $U$ concentrations and those of As and $\mathrm{Pb}(r=0.839$ and 0.845 , respectively $)$ in the same layers of CSM sediments suggest that, at different times, their characteristics have been determined by the nature of rocks of the area (see Fig. $\underline{5}$ ). The concentration of trace elements in core sediments was independent of age, and it would mean that their content does not depend strongly on climatic variables. On the contrary, the sedimentation rate of CSM seems to be correlated with rainfall (see Fig. $\underline{2}$ and Electronic Supplementary Material, Appendix 1).

The As and $\mathrm{Pb}$ concentrations in surface sediments correspond to their volcanic origin. Their mean values may be considered as a base level of the Chihuahua volcanic environment. On the other hand, $U$ occurrence in the core sediments corresponds to the content of this element in parent rocks of the San Marcos-Victorino deposits.

In the Granero area, CIW values were $\sim 70 \%$, which means a moderate 
leaching of $\mathrm{Ca}$ and $\mathrm{Na}$. As in the San Marcos area, the little difference between the CIW index values for surface sediments and sediment cores reflects the same amount of chemical weathering experienced by all weathered material.

In all sediment samples of the Granero reservoir, the EF values for $\mathrm{Pb}(0.8-$ 7.8) reflect a moderate to severe enrichment; for As (1.6-18.9), EF values imply a severe enrichment, and for $U(0.8-1.6)$, EF values reflect that there is no $U$ enrichment in the Granero area (Table 2). The CF and PLI values and the general behavior of trace element concentrations, together with their configurations in core samples, suggest an anthropogenic contamination that is variable in time and space at Granero area.

Surface sediment CF average values of 3.4 and 36.5 in the Granero reservoir indicate moderate to very severe pollution for $\mathrm{Pb}$ and $\mathrm{As}$, respectively. In the case of As, such CF values is due to high concentrations found in the sampling points G3, G4, and G5, which are impacted by sediment discharge in streams from nearby mines. For surface sediments, the PLI value of 8.5 is due to the high values of As and $\mathrm{Pb}$ and corresponds to an area affected by anthropogenic pollution.

The mean concentration of As of $102.1 \mathrm{mg} \mathrm{kg}^{-1}$ in G1-G7 (Table 2) is one order of magnitude higher than the value reported by Rice (1999). This author found an As baseline concentration in streambed sediment across the conterminous USA of $\sim 6$ to $9.2 \mathrm{mg} \mathrm{kg}^{-1}$. This mean As concentration is also one order greater than that of $13.3 \mathrm{mg} \mathrm{kg}^{-1}$ reported by Gutierrez et al. (2008) as the median value. The mean $\mathrm{Pb}$ concentration found in the present study was $48.9 \mathrm{mg} \mathrm{kg}^{-1}$, which is higher than the value of 27 to $44 \mathrm{mg} \mathrm{kg}^{-1}$ given by Rice (1999). The mean $\mathrm{U}$ concentrations are 
between 1.7 and $2.6 \mathrm{mg} \mathrm{kg}^{-1}$, and these values are of the same order of magnitude as the upper Earth crust concentration given by Taylor and McLennan (2003).

The As and Pb concentrations in dated sediment cores were higher in ECG than in OCG. This feature suggests that trace elements are filtered from water by the reservoir topographical features, preventing their further transport downstream to the Rio Grande. The behavior of As concentrations in ECG shows two different episodes through time. From 1982 to 1986, As concentrations were between 100 and $120 \mathrm{mg} \mathrm{kg}^{-1}$. Then, As concentrations were between 120 and $160 \mathrm{mg} \mathrm{kg}^{-1}$ from 1989 to 2004 . This behavior may be explained by an increase of the population and agriculture during those years. The use of groundwater in agriculture increased, and thus the occurrence of groundwater runoff at the surface (Gutierrez et al. 2009). The increase of As concentration does not appear to be due to rainfall directly, because, according to Fig. A.1.2 (Electronic Supplementary Material, Appendix 1), precisely at this time, there is no increase in rainfall in the upstream area of the Rio Conchos. Studies (e.g., Reyes Cortés et al. 2006a, $\underline{b}, \underline{c}$ ) showed a high concentration of As in groundwater, resulting from the presence of arsenopyrite in rocks. The decrease of As concentration in the upper layers in ECG in the last years may be related to the implementation of measures to prohibit the discharge of waste water into water bodies, beginning in 2004 (Fig. ㄱ).

Nevertheless, $U$ concentration did not show a high variability, either in ECG or in OCG (CV $<10 \%$ in each one), and the concentrations in the sediment cores and surface sediments did not show significant differences.

On the other hand, the distribution and increase of $\mathrm{Pb}$ concentration from 
1986 to 1997 can be associated with the Avalos lead smelter, which was established in the southeast of the city of Chihuahua, starting activities in 1908. During its last years of operation (it was shut down in 1993), the smelter produced about $250 \mathrm{t}$ of lead per day. Assays close to this area have reported a high content of $\mathrm{Pb}$ in atmospheric particulate matter (Ornelas Hicks et al. 2006). This suggests that those atmospheric particles were being removed and transported by the wind up to $90 \mathrm{~km}$ around. It is well known that the predominant wind direction in Chihuahua is from the southwest, which would explain that particles were being transported from the Avalos contaminated area to the entrance of the Granero reservoir. Apparently, the decreasing $\mathrm{Pb}$ concentration in the upper layers of the ECG core agrees with the closing years of the smelter operation.

As in the surface sediments, the ECG and OCG sediment cores showed CF average values indicating very strong and moderate pollution by $\mathrm{As}$ and $\mathrm{Pb}$, respectively. The mean value of the CF changes from 45.7 to 26 for the arsenic content, and changes from 2.3 to 1.3 for the lead content. The PLI is reduced from 9.4 in ECG to 2.9 in OCG. These values show again the cleaning effect on these trace elements along the reservoir.

\subsection{Radioactive isotope concentrations}

Figure $\underline{6}$ shows the activity concentration profiles for ${ }^{40} \mathrm{~K},{ }^{228} \mathrm{Ra},{ }^{226} \mathrm{Ra},{ }^{234} \mathrm{U}$, and ${ }^{238} \mathrm{U}$ isotopes in the three dated sediment cores. In Table $\underline{2}$, the mean values of their activity ratios are presented.

At San Marcos reservoir, activity concentration values were lower in 
surface sediments than in the sediment core. The ${ }^{40} \mathrm{~K},{ }^{228} \mathrm{Ra},{ }^{226} \mathrm{Ra}$, and ${ }^{238 \mathrm{U}} \mathrm{AC}$ mean values in surface sediments were $1164,377,856$, and $893.5 \mathrm{~Bq} \mathrm{~kg}^{-1}$, respectively; these results are like those found in parent rocks, reported in previous studies of the San Marcos-Victorino area (Reyes-Cortés et al. 2007, 2010; Luna Porres et al. 2011) and correspond to their sampling locations around the input basins of the reservoir. On the contrary, the ACs of core sediments are higher. These concentrations suggest that the deposition of radioactive species on core sediments corresponds to the characteristics of the water column (Rentería Villalobos et al. 2007), provided in part by the spring located in the bed of the reservoir near the point where the sediment core was extracted, and also to the sediment transport from the San MarcosVictorino $U$ deposits (see Table A4 from the Appendix 4, Electronic Supplementary Material).

Activity concentrations in both surface and core sediments are higher than those reported by UNSCEAR (2000) where reference values for the Earth's crust are $35,35,30$, and $400 \mathrm{~Bq} \mathrm{~kg}{ }^{-1}$ for ${ }^{226} \mathrm{Ra},{ }^{238} \mathrm{U},{ }^{232} \mathrm{Th}$, and ${ }^{40} \mathrm{~K}$, respectively. The ${ }^{234} \mathrm{U}$ and ${ }^{238} \mathrm{U}$ content shows a constant distribution (coefficient of variation $=10 \%)$ in core sediments.

Activity ratios (AR) of U-series isotopes help in analyzing (dis)equilibrium, and they may serve to reveal the relationship between factors such as weathering and adsorption (Chabaux et al. 2008). The ${ }^{234} \mathrm{U} /{ }^{238} \mathrm{U}$ AR in core sediments was between 1.1 and 1.4 with a mean of 1.2 , which are close 
to equilibrium. High AR values were found in layers close to the sedimentwater interface. This observation is consistent with those values reported for this reservoir water in Rentería Villalobos et al. (2007) — values which were obtained in a sampling performed at 2005 , when the water level in the reservoir was very low, and most of the water in the reservoir basin was probably supplied by the above-mentioned spring.

The ${ }^{40} \mathrm{~K},{ }^{228} \mathrm{Ra}\left({ }^{232} \mathrm{Th}\right)$, and ${ }^{226} \mathrm{Ra}$ ACs show a CV of $>20 \%$ in the sediment core profile. The increasing trend with depth of ${ }^{40} \mathrm{~K}$ AC shows two groups with different mean values; this behavior was checked by an ANOVA test. The observed difference may be attributed to anthropogenic origin, as an intensive exploration of $U$ deposits took place in the San Marcos and Victorino sites during the 1970s. For this reason, stones and other materials were moved, and roads were built, which may have blocked water or sediment with high potassium concentration from entering the water reservoir. ${ }^{228} \mathrm{Ra}\left({ }^{232} \mathrm{Th}\right)$ shows variability in the profile due to high AC found in the first and last layers; if these values were considered as outliers, the behavior of the ${ }^{228} \mathrm{Ra}\left({ }^{232} \mathrm{Th}\right)$ would be almost constant with depth, which could be explained by the low solubility of thorianite $\left(\mathrm{ThO}_{2}\right)$ and Th strong sorption onto the sediments. The ${ }^{226} \mathrm{Ra}$ ACs show a non-monotonic behavior in the core profile. The values of ${ }^{226} \mathrm{Ra} A C s$ divide the layers into two main groups, one for the layers closest to the surface, with $\mathrm{ACs}$ between 83 and $105 \mathrm{~Bq} \mathrm{~kg}^{-1}$, and the other group for the deepest layers, with ACs between 57 and $71 \mathrm{~Bq} \mathrm{~kg}^{-1}$. 
Fig. $6 \mathrm{U}$-series isotopes and ${ }^{40} \mathrm{~K}$ activity concentration profiles

$\left(\mathrm{Bq} \mathrm{kg}^{-1}\right)$ in the three dated sediment cores. CSM means core from San Marcos reservoir, ECG —entrance core from Granero reservoir and

OCG-northern core from Granero reservoir

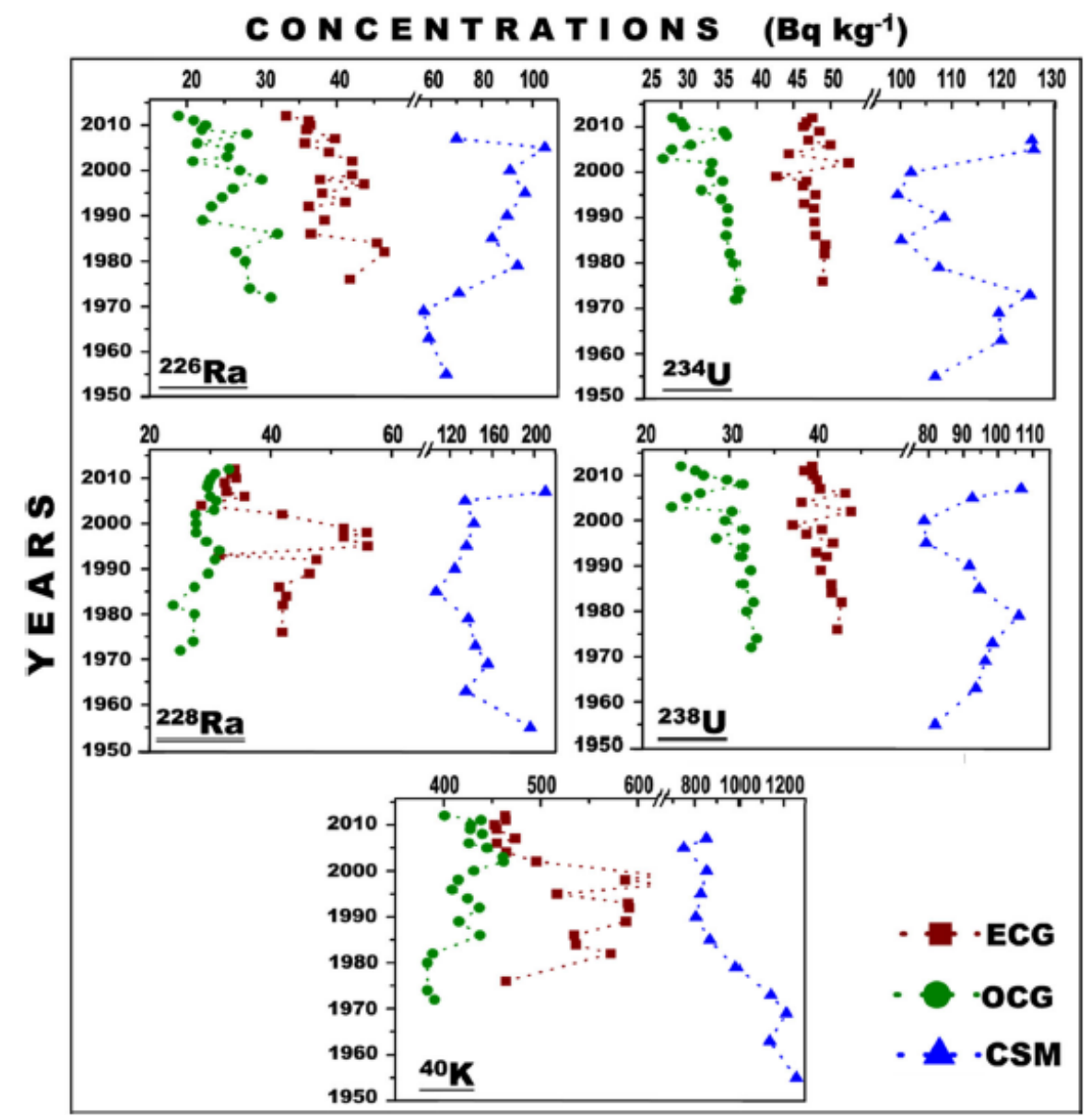

This behavior suggests that reducing conditions in deep strata prevail where ${ }^{226} \mathrm{Ra}$ is more soluble while, in shallow layers, oxidation conditions could be found.

The ${ }^{238} \mathrm{U}$-and ${ }^{232} \mathrm{Th}$-series isotopes commonly occur together in nature; the ${ }^{232} \mathrm{Th} / 238 \mathrm{U}$ mass ratio is around 3.5 in almost all natural systems (Ivanovich and Harmon 1992). The mean AR value in the Earth's crust is 1.2 (Porcelli and Swarzenski 2003). The ${ }^{228} \mathrm{Ra}\left({ }^{232} \mathrm{Th}\right) / 238 \mathrm{U}$ AR mean value in the sediment core was higher than 1.2. The ${ }^{238} \mathrm{U} / 226 \mathrm{Ra}$ ARs show disequilibria $(A R \neq 1)$ in 
the ${ }^{238} \mathrm{U}$ chain at the first layer and the deepest four in the sediment core, where AR values between 1.3 and 1.7 were found. This behavior may be logically explained by their differential ion mobility (O'Reilly et al. 2011). The mean ${ }^{228} \mathrm{Ra}\left({ }^{232} \mathrm{Th}\right) / 226 \mathrm{Ra}$ AR value in the core was 1.8 , which is higher than the AR of 1.1 reported by Harbottle and Evans (1997) in most environmental samples. Usually, this AR is applied to assess the conservation of the proportion within the ${ }^{232} \mathrm{Th}$ and ${ }^{238} \mathrm{U}$ decay series. Thereby, in this sediment core, the regular proportion has not been preserved.

At the Granero reservoir and its vicinity, the activity concentrations of Useries isotopes were higher in ECG than in OCG and G1-G7, suggesting they are transported by the different streams arriving at the reservoir. The ${ }^{238} \mathrm{U}$ and ${ }^{226} \mathrm{Ra}$ ACs did not show significant differences between sediment cores or surface sediments (Table $\underline{3}$ ). Only the ACs values of ${ }^{40} \mathrm{~K}$ were above the reference value $400 \mathrm{~Bq} \mathrm{~kg}^{-1}$ determined by UNSCEAR (2000). The high concentration of potassium corresponds to the feldspar appearing in the diffraction patterns (see Electronic Supplementary Material, Appendix 2).

\section{Discussion}

Comparison of temporal dependencies of $\mathrm{As}, \mathrm{Pb}$, and $\mathrm{U}$ concentrations among the three cores of the two reservoirs studied is displayed in Fig. $\underline{7}$. 
Table 3 Comparison of trace elements and radioactive isotopes concentrations among core and surface sediments in Granero and San Marcos reservoirs

\begin{tabular}{lllllllll}
\hline Sample ID & As & $\mathrm{Pb}$ & $\mathrm{U}$ & ${ }^{232} \mathrm{Th}$ & ${ }^{238} \mathrm{U}$ & ${ }^{26} \mathrm{Ra}$ & ${ }^{40} \mathrm{~K}$ & ${ }^{137} \mathrm{Cs}$ \\
\hline G1-G7 & A & B & B & B & B & A & A & B \\
ECG & A & A & A & B & B & A & B & A \\
OCG & B & B & B & A & A & A & A & A \\
SM1-SM5 & B & B & B & A & A & A & A & A \\
CSM & A & A & A & B & B & B & B & B \\
\hline
\end{tabular}

Letters A or B represent significant differences between the observed concentration values

These results show the differences in location, lithology, and environmental conditions of the sites. Approximately 30 times greater concentration level of $U$ is observed in CSM.

This radioelement is practically not transported to the Granero reservoir. Conversely, concentrations of $\mathrm{As}$ and $\mathrm{Pb}$ in CSM are generally lower than in ECG and OCG. The concentrations of $\mathrm{As}, \mathrm{Pb}$, and $\mathrm{U}$ are greatly reduced from ECG to OCG. Consequently, water and sediments appear to be cleaned while transported in the Granero reservoir.

Mean concentrations of $A s$ and $P b$ were found higher in G1-G7 than in SM1-SM5. The low CV (Table 2) in trace element concentrations at CSM suggests that this behavior is the proper base level of San MarcosSacramento Valley, where high correlations between these elements were found. It has also been observed that As has slightly higher levels in deep wells at the San Marcos area (Burillo Montufar et al. 2012). Meanwhile, the 
high $\mathrm{Pb}$ contents in sediments at the San Marcos area is attributed to its presence in some uraniferous rocks (Reyes-Cortés et al. 2010).

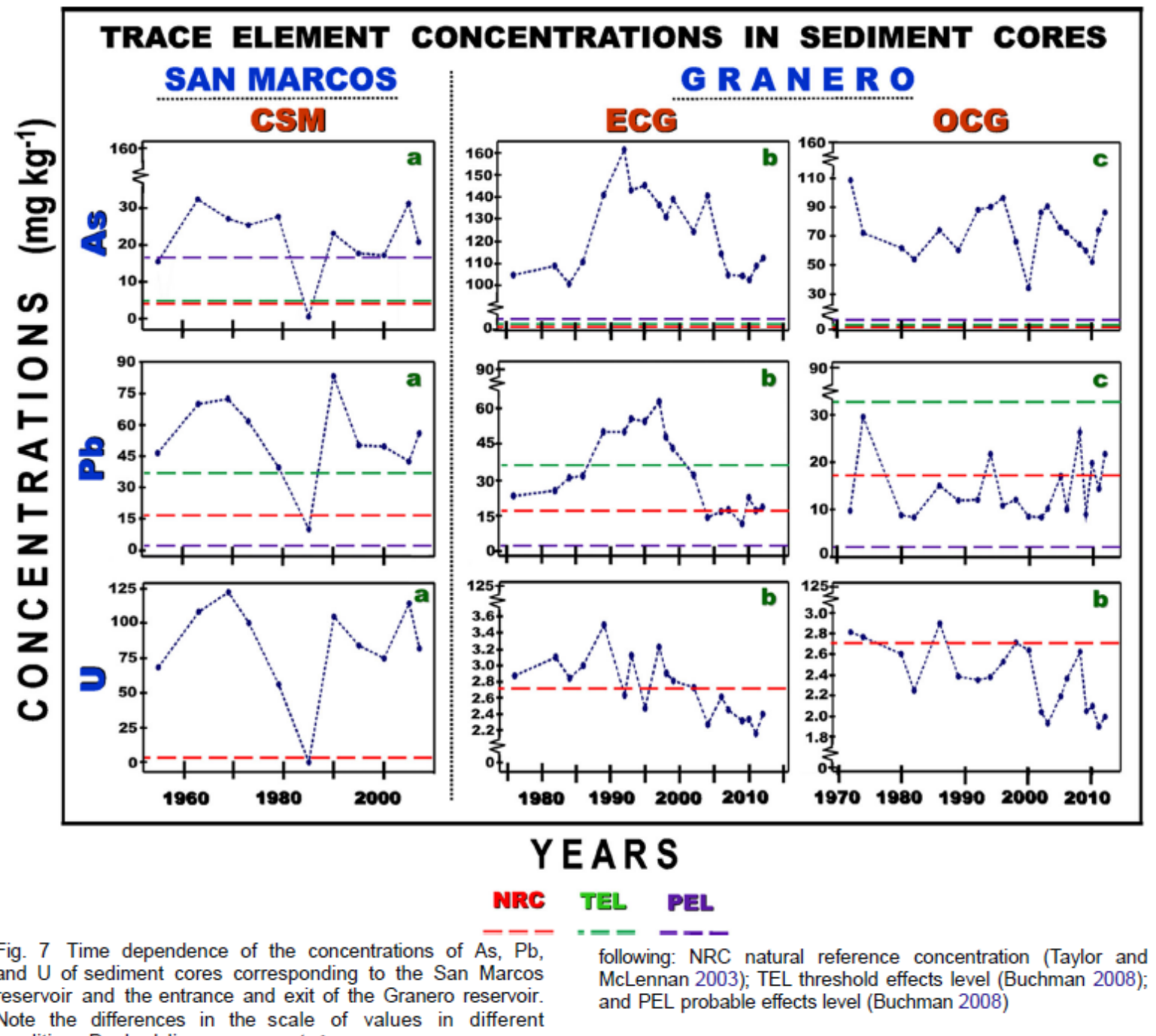

Note the differences in the scale of values in different localities. Dashed lines represent the 
Fig. 8 Arsenic (As), lead $(\mathrm{Pb})$, and uranium $(\mathrm{U})$ concentrations in the surface sediments of the Granero reservoir. Note the scale differences between the As, $\mathrm{Pb}$, and $\mathrm{U}$ concentrations
GRA NERO RESER V O IR

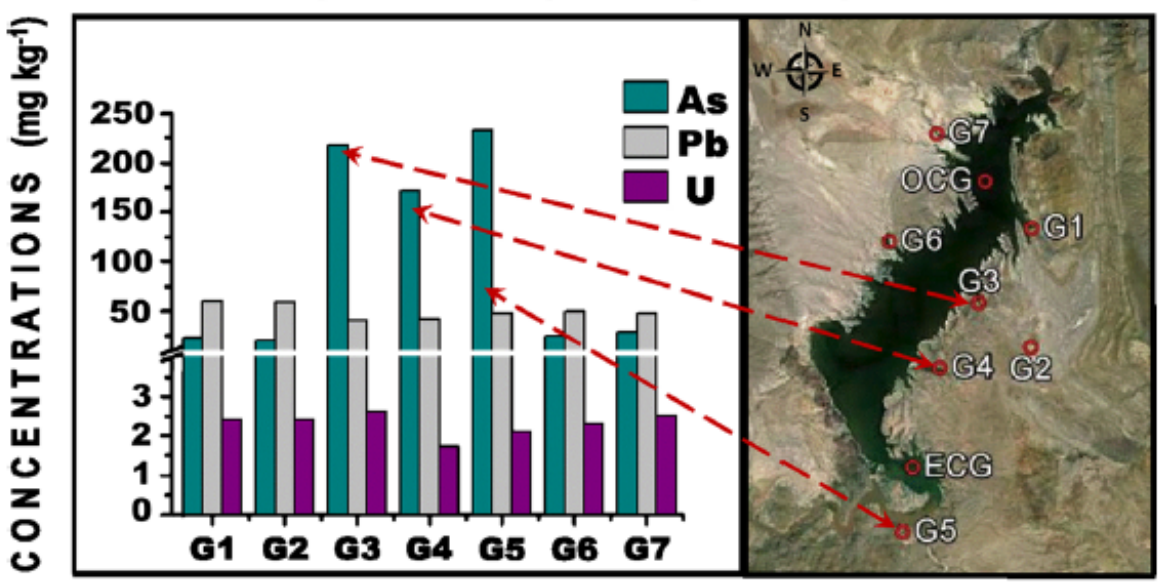

SURFACE SEDIMENTS

On the other hand, the temporal variability of $\mathrm{As}$ and $\mathrm{Pb}$ in sediment cores at the Granero reservoir may be explained by variations of anthropogenic pollution, as these changes match with events when both As and $\mathrm{Pb}$ were more available in the state of Chihuahua. Fortunately, this pollution has been declining in recent years according to the dating and distribution of $\mathrm{As}$ and $\mathrm{Pb}$ in ECG and OCG.

In all sediment samples but the SMS ones, there are As concentrations higher than the threshold effect level (TEL) and probable effect level (PEL) values. These concentration values might cause adverse effects to human health, since both reservoirs are used for fishing. The $\mathrm{Pb}$ concentrations in all analyzed samples are below the reference value (PEL), whereas concentrations of $\mathrm{Pb}$ at some depths in ECG are above the TEL value. This feature is attributed to the influence of air pollution from the former Avalos smelter (Ornelas Hicks et al. 2006) into the Granero reservoir, and, consequently, this level has not been exceeded in recent years. 
The low $\mathrm{As}, \mathrm{Pb}$, and $\mathrm{U}$ concentrations in $\mathrm{OCG}$ and the values below detection limits in water, at ECG and OCG sampling locations, suggest that these elements have been available in negligible concentrations in the water supplied by the Granero reservoir. Moreover, $U$ concentrations were one order of magnitude higher in SMS and CSM than in sediments from the Granero reservoir area. These results suggest that erosion and weathering of rocks from Victorino $U$ deposit in the San Marcos area have no influence in recent times through all the low Rio Conchos subbasin, despite being responsible for high $U$ concentrations in groundwater of the ChihuahuaSacramento Valley (Reyes Cortés 2009; Reyes-Cortés et al. 2010).

Mean concentrations of $\mathrm{As}$ and $\mathrm{Pb}$ in surface sediments in the San Marcos area could be considered as natural concentration levels (NCL) for Chihuahua state, whereas the natural mean concentration of $U$ in the Granero area could be taken as NCL, all of them having the meaning of nonanthropogenic influence. The NCLs in the Chihuahua State established for $\mathrm{As}, \mathrm{Pb}$, and $\mathrm{U}$ in the present work are $2.8,14.2$, and $2.3 \mathrm{mg} \mathrm{kg}^{-1}$, respectively.

Figure $\underline{8}$ shows the concentrations of $\mathrm{As}, \mathrm{Pb}$, and $\mathrm{U}$ in the surface sediments of the Granero reservoir, which are detailed in Table A.3 (Electronic Supplementary Material). Detection of much lower concentrations of As in the core OCG confirms the cleaning effect of the transport of pollutants along the reservoir. 


\section{Conclusions}

A characterization of major, trace, and radioactive elements was obtained from surface and core sediments sampled at the two reservoirs in Chihuahua State. The radio-chronology in sediment cores from San Marcos and El Granero allowed proposals for both distribution and origin of the concentrations of trace and radioactive elements. The high EFs found at the Granero area for $\mathrm{As}$ and $\mathrm{Pb}$ indicated an anthropogenic influence at specific time intervals. According to the radioactive isotope analysis, their high activity concentrations in the San Marcos area are natural in origin. The relative higher activity concentrations in the San Marcos sediment core indicate that they do retain the radioactive characteristics of the rocks nearby Victorino $U$ deposit. Besides, these elements have not been transported throughout the low Rio Conchos basin in recent times, thus decreasing the activity concentrations found in the Granero's area. Natural concentration levels for $\mathrm{As}, \mathrm{Pb}$, and $\mathrm{U}$ in sediments were established in Chihuahua State. The concentrations of As in CSM, G1-G7, ECG, and OCG were found above the TEL and PEL values, thus indicating the possibility of adverse effects to human health. An estimation of possible risks by As ingestion in the San Marcos and the Granero reservoirs is suggested.

\section{Acknowledgments}

We acknowledge the support given by the Consejo Nacional de Ciencia y Tecnología Projects FOMIX CHIH-2011-C03-167723 and CB-01-2011- 
166697 and by the Centro de Investigación en Materiales Avanzados (CIMAV).

\section{References}

1. Abril JM (2003) Difficulties in interpreting fast mixing in the radiometric dating of sediments using 210Pb and 137Cs. J Paleolimnol 30:407-414

2. Alonso-Hernandez CM, Diaz-Asencio M, Munoz-Caravaca A, Delfanti R, Papucci C, Ferretti O, Crovato C (2006) Recent changes in sed-imentation regime in Cienfuegos bay, Cuba, as inferred from $210 \mathrm{~Pb}$ and $137 \mathrm{Cs}$ vertical profiles. Cont Shelf Res 26:153-167

3. Appleby PG, Nolan PJ, Oldfield F, Richardson N, Higgitt SR (1988) 210Pb dating of lake sediments and ombrotrophic peats by gamma essay. Sci Total Environ 69:157-177

4. Aslani MAA, Akyil S, Aytas S, Gurboga G, Eral M (2005) Activity concentration of $210 \mathrm{~Pb}(210 \mathrm{Po})$ in soils taken from cultivated lands. Radiat Meas 39:129-135

5. Benin AL, Sargent JD, Dalton M, Roda S (1999) High concentrations of heavy metals in neighborhoods near ore smelters in northern Mexico. Environ Health Perspect 107:279-284

6. Bertolino SRA, Zimmermann U, Sattler FJ (2007) Mineralogy and geochemistry of bottom sediments from water reservoirs in the vicinity of Cordoba, Argentina. Environmental and health constraints. Appl Clay Sci $36: 206-220$ 
7. Birch GF, Olmos MA (2008) Sediment-bound heavy metals as indicators of human influence and biological risk in coastal water bodies. ICES J Mar Sci 65:1407-1413

8. Buchman MF (2008) NOAA screening quick reference tables. National Oceanic and Atmospheric Administration, Seattle, WA, USA

9. Burillo Montufar JC, Reyes Cortés M, Reyes Cortés IA, Espino Valdez MS, Hinojosa de la Garza OR, Nevárez Ronquillo DP, Herrera Peraza E, Rentería Villalobos M, Montero Cabrera ME (2012) Uranium-series isotopes transport in surface, vadose and ground waters at San Marcos uranium bearing basin, Chihuahua, Mexico. Appl Geochem 27:1111-1122

10. Camacho LM, Gutierrez M, Alarcon-Herrera MT, Villalba ML Deng S (2011) Occurrence and treatment of arsenic in ground-water and soil in northern Mexico and southwestern USA. Chemosphere 83:211-225

11. Cameron M, Bagby W, Cameron K (1980) Petrogenesis of voluminous midtertiary ignimbrites of the Sierra Madre Occidental, Chihuahua, Mexico. Contrib Mineral Petrol 74:271-284

12. Carrizales L, Razo I, Téllez-Hernández JI, Torres-Nerio R, Torres A, Batres LE, Cubillas A-C, Díaz-Barriga F (2006) Exposure to arsenic and lead of children living near a copper-smelter in San Luis Potosi, Mexico: importance of soil contamination for exposure of children. Environ Res 101:1-10

13. Chabaux F, Bourdon B, Riotte J (2008) Chapter 3 U-series geochemistry in weathering profiles, river waters and lakes. In: Porcelli D, Krishnaswami S, Cochran JK (eds) Radioactivity in the environ-ment, vol Volume 13. Elsevier, 
pp 49-104

14. Ferríz H (1985) Uranium mineralization in the San Marcos volcanic center Chihuahua, Mex. In: Uranium deposits in volcanic rocks, El Paso, Texas, 2-5 Abril 1984. IAEA, Vienna, Austria, pp 197-216

15. Fierro V, Muñiz G, Gonzalez-Sánchez G, Ballinas ML, Celzard A (2009) Arsenic removal by iron-doped activated carbons prepared by ferric chloride forced hydrolysis. J Hazard Mater 168:430-437

16. Flores-Tavizón E, Alarcón-Herrera M, González-Elizondo S, Olguín EJ (2003) Arsenic tolerating plants from mine sites and hot springs in the semi-arid region of Chihuahua, Mexico. Acta Biotechnol 23: 113-119

17. Garcia Agudo E (1998) Global distribution of 137Cs inputs for soil erosion and sedimentation studies. In: Use of 137Cs in the study of soil erosion and sedimentation. IAEA, Vienna, Austria

18. García-Tenorio García-Balmaseda R (1986) Estudios sobre el método de fechado por 210Pb y su aplicación a sedimentos. Universidad de Sevilla, Spain

19. Gutiérrez M, Carreon E (2008) Contenido de As, Ba, y Cu en sedimentos y su asociación con depósitos minerales en el noreste de Chihuahua. Tecno ciencia Chihuahua II:108-117

20. Gutiérrez M, Martínez-Pina C, Luo J, Mickus K (2008) Geochemical processes contributing to the contamination of soil and surface wa-ters in the Rio Conchos basin, Mexico. Geosphere 4:600-611

21. Gutiérrez M, Alarcón-Herrera M, Camacho L (2009) Geographical distribution 
of arsenic in sediments within the Rio Conchos Basin, Mexico. Environ Geol 57:929-935

22. Gutiérrez M, Reyes Gómez VM, Alarcón Herrera MT, Núñez López D (2012) Exploratory analysis of sediment geochemistry to determine the source and dispersion of $\mathrm{Ba}, \mathrm{Fe}, \mathrm{Mn}, \mathrm{Pb}$ and $\mathrm{Cu}$ and in Chihuahua, Northern Mexico. J Geogr Geol 4:26-39

23. Hakanson L (1980) An ecological risk index for aquatic pollution control. A sedimentological approach. Water Res 14:975-1001

24. Hallstadius L (1984) A method for the electrodeposition of actinides. Nucl Instrum Methods Phys Res 223:266-267

25. Harbottle G, Evans C (1997) Gamma-ray methods for determining natural and anthropogenic radionuclides in environmental and soil sci-ence. Radioact Radiochem 7:38-47

26. Harnois $L$ (1988) The CIW index: a new chemical index of weathering. Sediment Geol 55:319-322

27. Hernández Noriega L, Carrizales Aguilar A, Ávila Lugo F, Ramírez Tello E (2002) Carta Ciudad Delicias h13-11, 1:250,000 Servicio Geológico Mexicano, Mexico

28. INEGI (1999) Estudio hidrológico del estado de Chihuahua vol ISBN: 9701320778, Primera edn. Instituto Nacional de Estadística Geografía e Informática, Aguas Calientes, México

29. Ivanovich M, Harmon RS (1992) Uranium-series disequilibrium: applications to earth, marine, and environmental sciences. Clarendon, Oxford 
30. Luna Porres MY, Alarcón Herrera MT, Silva Sáenz Rentería, Villalobos M, Rodríguez Villa MA, Herrera Peraza E, Reyes Cortés M, Montero Cabrera ME (2011) Baccharis salicifolia development in the presence of high concentrations of uranium in the arid environment of San Marcos, Chihuahua. Rev Mex Fis 57:40-43

31. MacDonald DD (1994) Approach to the assessment of sediment quality in Florida coastal waters. Florida Department of Environmental Protection, Tallahassee, Florida, USA

32. Méndez C, Esparza-Ponce H, Beesley A, Crespo M, Fuentes L, FuentesMontero L, Murillo G, Varela A, Montero-Cabrera M (2010) Nanoscopic study of chemical species during uranium electrodepo-sition for alpha spectrometry sources. J Mater Sci 45:5061-5070

33. Montero Cabrera ME, Rentería Villalobos M, Reyes Cortés M, Burciaga Valencia D, Silva Sáenz M, Reyes Cortés I, Herrera Peraza EF (2007) Contaminación natural con uranio del agua subterránea en el valle de Chihuahua-Sacramento: características y origen. Paper presented at the VI Congreso Internacional y XII Nacional de Ciencias Ambientales, Chihuahua, México

34. O’Reilly J, León Vintró L, Mitchell PI, Donohue I, Leira M, Hobbs W, Irvine K (2011) 210Pb-dating of a lake sediment core from Lough Carra (Co. Mayo, Western Ireland): use of paleolimnological data for chronology validation below the 210Pb dating horizon. J Environ Radioact 102:495-499

35. Ornelas Hicks M, Sanín Aguirre LH, Díaz-Barriga F, Reza López SA, Romieu 
I (2006) Risk assessment in an old lead smelter complex in Chihuahua, México. Tecnociencia Chihuahua 1:26-35

36. Pandey B, Agrawal M, Singh S (2016) Ecological risk assessment of soil contamination by trace elements around coal mining area. J Soils Sediments 16:159-168

37.Porcelli D, Swarzenski PW (2003) The behavior of U- and Th-series nuclides in groundwater. Rev Mineral Geochem 52:317-361

38. QiS,LeipeT,RueckertP,DiZ,Harff J (2010) Geochemical sources, deposition and enrichment of heavy metals in short sediment cores from the Pearl River estuary, southern China. J Mar Syst 82:S28-S42

39. Reimann C, Caritat $P$ (2000) Intrinsic flaws of element enrichment factors (EFS) in environmental geochemistry. Environ Sci Technol 34: 5084-5091

40. Rentería Villalobos M, Montero Cabrera ME, Rodríguez Pineda A, Reyes Cortés M, Herrera Peraza EF, Valenzuela Hernández M (2005) Uranium series specific activities of rocks forming ranges around Chihuahua City, Mexico. Paper presented at the 2nd International Conference on Radioactivity in the Environment, October 2-6, Nice, France

41. Rentería Villalobos M, Montero Cabrera ME, Reyes Cortés M, Herrera Peraza EF, Rodríguez Pineda A, Manjón Collado G, García Tenorio R, Crespo T, Valenzuela Hernández M (2007) Characterization of source rocks and groundwater radioactivity at the Chihuahua Valley. Rev Mex Fis S53:1622

42. Rentería-Villalobos M, Reyes Cortés M, Mantero J, Manjón G, García- 
Tenorio R, Herrera E, Montero-Cabrera ME (2012) Uranium in the surrounding of San Marcos-Sacramento River environment (Chihuahua, México).SciWorldJ.doi:10.1100/2012/616430

43. Reyes Cortés M (2009) Caracterización de los minerales de uranio del área de San Marcos, Chihuahua. Influencia hidrogeológica, Centro de Investigación en Materiales Avanzados, México

44. Reyes Cortés IA, Precoma Mojarro AY, Villalba L, Reyes Cortés M, Barrera Prieto Y, Ledesma Ruiz R (2006a) Presencia de as en Chihuahua, Chihuahua, México. Geos 26:40

45. Reyes Cortés IA, Reyes Cortés M, Villalba L, Montero Cabrera ME, Ledesma Ruiz R, Barrera Prieto Y, Precoma Mojarro AY, Vázquez Balderas JF (2006b) Origen del As en las cuencas endorreicas, Chihuahua, México. Geos 26:39

46. Reyes Cortés IA, Vázquez Balderas JF, Ledesma Ruiz R, Reyes Cortés M, Barrera Prieto Y (2006c) As en el sistema hidrogeológico del valle de Delicias, Chihuahua, México. Geos 26:40

47. Reyes-Cortés M, Montero-Cabrera ME, Renteria-Villalobos M, FuentesMontero L, Fuentes-Cobas L, Herrera-Peraza EF, Esparza-Ponce H, Rodriguez-Pineda A (2007) Radioactive mineral samples from the northwest of Chihuahua City, Mexico. Rev Mex Fis S53:23-28

48. Reyes-Cortés M, Fuentes-Cobas L, Torres-Moye E, Esparza-Ponce H, Montero-Cabrera M (2010) Uranium minerals from the San Marcos District, Chihuahua, México. Mineral Petrol 99:121-132

49. Reyes-Cortés M, Reyes-Cortés IA, Espino Valdez S, Rentería-VillalobosM, 
Burillo Montúfar JC, Montero-Cabrera ME (2012) Origen y distribución de la radiactividad natural en la zona norte de la cuenca de Chihuahua, México. Rev Mex Cien Geol 29:659-675

50. Reyes-Gómez V, Alarcón-Herrera M, Gutiérrez M, López D (2013) Fluoride and arsenic in an alluvial aquifer system in Chihuahua, Mexico: contaminant levels, potential sources, and co-occurrence. Water Air Soil Pollut 224:1-15

51. Rice KC (1999) Trace-element concentrations in streambed sediment across the conterminous United States. Environ Sci Technol 33: 2499-2504

52. Ritchie JC, McHenry JR (1990) Application of radioactive fallout Cesium-137 for measuring soil erosion and sediment accumulation rates and patterns: a review. J Environ Qual 19:215-233

53. Ruiz-Fernández AC, Páez-Osuna F, Urrutia-Fucugauchi J, Preda M (2005) $210 \mathrm{~Pb}$ geochronology of sediment accumulation rates in Mexico City metropolitan zone as recorded at Espejo de los Lirios lake sediments. Catena $61: 31-48$

54. Ruiz-Fernández AC, Hillaire-Marcel C, Páez-Osuna F, Ghaleb B, Caballero M (2007) $210 \mathrm{~Pb}$ chronology and trace metal geochemis-try at Los Tuxtlas, Mexico, as evidenced by a sedimentary record from the Lago Verde Crater Lake. Quaternary Res 67:181-192

55. Sanchez-Cabeza J, Masqué P, Ani-Ragolta I (1998) 210Pb and 210Po analysis in sediments and soils by microwave acid digestion. J Radioanal Nucl Chem 227:19-22

56. Sánchez-Cabeza J-A, Díaz-Asencio M, Ruiz-Fernández AC (eds) (2012) 
Radio cronología de sedimentos costeros utilizando 210Pb: modelos, validación y aplicaciones. Vol STI/PUB/1538. IAEA, Vienna, Austria

57. Sanin LH, Alarcon-Herrera MT, Ornelas M, Díaz-Barriga F, Reza S, Romieu I (2006) Risk assessment and remediation proposals in an abandoned lead smelter complex in Chihuahua, Mexico. Epidemiol 17:S124

58. Schropp SJ, Lewis FG, Windom HL, Ryan JD, Calder FD, Burney LC (1990) Interpretation of metal concentrations in estuarine sediments of Florida using aluminum as a reference element. Estuaries 13:227-235

59. Shumilin EN, Carriquiry JD, Camacho-Ibar VF, Sapozhnikov D, Kalmykov S, Sánchez A, Aguíñiga-García S, Sapozhnikov YA (2002) Spatial and vertical distributions of elements in sediments of the Colorado River delta and upper Gulf of California. Mar Chem 79:113-131

60. Talvitie NA (1972) Electrodeposition of actinides for alpha spectrometric determination. Anal Chem 44:280-283

61. Taylor SR, McLennan SM (2003) Chemical composition and element distribution in the earth's crust. In: Meyers RA (ed) Encyclopedia of physical science and technology, 3rd edn. Academic Press, New York, USA, pp 697719

62. Tomlinson DL, Wilson JG, Harris CR, Jeffrey DW (1980) Problems in the assessment of heavy-metal levels in estuaries and the formation of a pollution index. Helgolander Meeresunters 33:566-575

63. UNSCEAR (2000) Sources and effects of ionizing radiation, Annex B: exposures from natural radiation sources. United Nations Scientific 
Committee on the Effects of Atomic Radiation (UNSCEAR), New York

64. Varol M (2011) Assessment of heavy metal contamination in sediments of the Tigris River (Turkey) using pollution indices and multivariate statistical techniques. J Hazard Mater 195:355-364

65. Vicente-Vicente L, Quiros Y, Pérez-Barriocanal F, López-Novoa JM, LópezHernández FJ, Morales AI (2010) Nephrotoxicity of urani-um: pathophysiological, diagnostic and therapeutic perspectives. Toxicol Sci 118:324-347

66. Villalba L, Montero-Cabrera ME, Manjon-Collado G, Colmenero-Sujo L, Rentería-Villalobos M, Cano-Jiménez A, Rodríguez-Pineda A, Dávila-Rangel I, Quirino-Torres L, Herrera-Peraza EF (2006) Natural radioactivity in groundwater and estimates of committed effective dose due to water ingestion in the State of Chihuahua (México). Radiat Prot Dosim 121:148-157

67.Walling DE, He Q (1997) Use of fallout 137Cs in investigations of overbank sediment deposition on river floodplains. Catena 29:263-282

68. Welch AH, Lico MS, Hughes JL (1988) Arsenic in ground water of the western United States. Ground Water 26:333-347

69. Wendt CJ (2002) The geology and exploration potential of the Guigui Silver, Lead, Zinc project Santa Eulalia District, Chihuahua, Mexico Pincock, Allen \& Holt,, , Mexico

70. WHO (2012) Arsenic, fact sheet. http://www.who.int/mediacentre/factsheets/fs372/en/\#. Accessed 27 Sept 2013 
71. Zhang J, Liu CL (2002) Riverine composition and estuarine geochemistry of particulate metals in China—weathering features, anthropogenic impact and chemical fluxes. Estuar Coast Shelf Sci 54:1051-1070 Zoller WH, Gladney ES, Duce RA (1974) Atmospheric concentrations and sources of trace metals at the South Pole. Science 183:198-200 